\title{
Hydrology and the looming water crisis: It is time to think, and act, outside the box
}

\author{
Philippe C. Baveye ${ }^{1,2}$ \\ ${ }^{1}$ Laboratory of Soil and Water Engineering, Department of Civil and Environmental Engineering, Rensselaer Polytechnic Institute, Jonsson \\ Engineering Center, 110 8th street, Troy, New York 12180, USA. \\ ${ }^{2}$ SIMBIOS Centre, Abertay University, Kydd Building, 40 Bell Street, Dundee DD1 1HG, Scotland. \\ E-mail: Baveye.RPI@gmail.com
}

In a number of respects, it is exciting to be a hydrologist these days.

Very innovative work has been published lately, and it deservedly generates a lot of enthusiasm and intellectual excitement. In this journal alone, several very interesting articles (Budagovskyi and Novak, 2011a,b; Doležal et al., 2012; Kovář et al., 2012; Machlica et al., 2012; Pavelková et al., 2012) have recently contributed in a significant manner to increase our understanding of key aspects of mainstream hydrology and water resources. A number of areas have seen particularly interesting advances. Some of the most stimulating developments in recent years have been in the significant broadening of spatial scales at which we can now investigate the fate and transport of water in the environment, and in the opening up of hydrology to other disciplines, like biology and ecology, which has allowed water-related processes to be studied from novel vantage points.

Thanks to amazing technological advances during the last decade, especially in terms of X-ray computed tomography, it is now possible to obtain detailed, micron-scale information about the geometry of the spaces through which water and the solutes it carries percolate in natural porous media. There are still some practical issues to work out with this technology, like the thresholding of 3D images of soils to produce binary blackand-white images (e.g., Baveye et al., 2010; Houston et al., 2013; Schlueter et al., 2010), but nevertheless the fundamental information CT scans can afford has already led to new insight concerning, e.g., the influence of soil architecture on processes occurring in soils (Baveye et al., 2011). These microscopic data have spurred interest in non-traditional approaches to the modeling of water and solute transport, using for example the Lattice-Boltzmann approach (e.g., Baveye et al., 2010; Falconer et al., 2012; Vogel et al., 2005), which is definitely a step forward compared to classical approaches to pore-scale modeling, involving artificial networks of cylindrical capillaries (e.g., Thullner and Baveye, 2008). At the other extreme of the scale spectrum, advances in satellite sensing technology and software are allowing hydrologists to monitor broad features of the water cycle, like the depletion of groundwater storage in various parts of the world (e.g., Anderson et al., 2012), or the spatial distribution of water-related ecosystems like wetlands and marshes (e.g., Laba et al., 2008).

The combination of hydrology with biology and in particular ecology, has been one of the key developments of the last two decades. Starting with Slichter (1905), hydrologists have been keenly aware for over a century of possible connections between microorganisms and the hydraulic and transport properties of soils and aquifers, and Slichter's (1905) observations have been followed by many others (Allison, 1947; Darnault et al., 2003; DeLeo and Baveye, 1997; DeLozada et al., 1994;
Gupta and Swartzendruber, 1962; Jacobson et al., 2005; Qureshi et al., 2003). Nevertheless, these research efforts were very focalized on specific issues, like the bioclogging of soils or the transport of pathogens and contaminants, and did not attempt to envisage all the possible ways in which biology and ecology have bearing on water resources. This more systematic perspective has been explored by increasing numbers of researchers over the last 20 or so years, yielding valuable insight about numerous processes (e.g., Lichner et al., 2012). One particularly positive feature of this trend has been the fact that, even though some researchers are talking about "biohydrology" and "ecohydrology" as if their intent were to create new disciplines (with all that this implies of launching new journals, creating dedicated scholarly societies, holding separate meetings), researchers by and large have resisted the urge to do so. The terms "biohydrology" and "ecohydrology" appear to serve occasionally as rallying calls for focused conferences and special issues of journals, but otherwise researchers who work in these areas are still very much integrated in the whole hydrology community, which from my perspective is a very good thing (Baveye, 2011).

So, there are many reasons to feel upbeat about the way hydrology and research on water resources are evolving. However, there are also several reasons to be concerned about the future. One of these reasons has to do with the tremendous increase we are currently experiencing not only in the number of published articles in the field, but also in the number of new journals cropping up continuously, supposedly to satisfy the exploding publishing demand. Elsevier, for example, recently announced the launching of no less than four new Water Resources journals. The sad thing about this publishing frenzy is that one the key reasons so many articles are published, and new journals are being created unnecessarily when traditional journals should suffice, is that administrators of universities and research centers, particularly in the US but now also in other countries, persist in using meaningless metrics, like the yearly number of published articles, to gage faculty productivity (e.g., Baveye, 2010; Siegel and Baveye, 2010; Trimble et al., 2010). The paper glut, which results from this lack of vision and could be easily alleviated, is nothing to be excited about, unfortunately. It is not at all clear who besides the publishers themselves will profit from all the new journals being launched, who will be reviewing the masses of manuscripts that are produced, or, perhaps most importantly, who will have time to read the tens of thousands of articles that eventually get published. In this last respect, particularly, it is not obvious at all who will be able to carry out the integrative, interdisciplinary research that is needed to deal with increasingly complex water-related issues, once researchers will have been forced to specialize into extremely narrow subdisciplines to be able to keep up with an 
ever-shrinking fraction of the literature. Under these conditions, interdisciplinary efforts that simultaneously involve hydrology and biology, or hydrology and ecology, resulting in very high demands in terms of reading the literature, may turn out to be hard to sustain in the long run.

Another cause for concern at the moment has to do with the fact that hydrologists, at least in their writings, seem reluctant to deal with pressing and unprecedented societal questions related to water resources (Baveye, 2012). Among the masses of manuscripts submitted to hydrology and water resources journals, few deal directly with topical issues like global warming, climate change, water scarcity, water shortage, or food security. The numbers in this respect are depressing. According to the Web of Knowledge (Thomson Reuters, New York), of the articles published by Water Research, Hydrology and Earth System Sciences, Water Resources Research, the Journal of Hydrology, Advances in Water Resources, and the Journal of Hydrology and Hydromechanics between 2007 and 2012, only $0.3 \%, 20 \%, 6 \%, 11.8 \%, 3.8 \%$, and $4 \%$, respectively, had one of the above terms in their title, abstract, or list of keywords. In other words, in only one journal (HESS) did the portion of articles dealing with critical water-related issues get to about a fifth of the total number of published articles in that journal, while $80 \%$ pursue business as usual! There are probably several ways to look at these numbers. Nevertheless, they suggest that, for whatever reasons (the legitimate fear to appear as ambulance chasers might be one), hydrologists and water resources experts are reluctant to frame their research openly within the context of any of the water-related debates of the moment, at least when they write articles.

And yet, the problems that we are likely to face in this area are formidably daunting. According to many experts, we are heading straight for a major global water crisis, which will affect all parts of the planet in one way or another. Many authors have written on the issue (e.g., Fendeková and Fendek, 2012; Hanel et al., 2012; Hanjra and Qureshi, 2010; Jury and Vaux, 2005, 2007; McDonald, 2011; Němečková et al., 2012; Schwartz and Ibaraki, 2011). Jury and Vaux (2007) have summarized the situation very clearly: "In the absence of coordinat- ed planning and international cooperation at an unprecedented scale, the next half century will be plagued by a host of severe water-related problems, threatening the well being of many terrestrial ecosystems and drastically impairing human health, particularly in the poorest regions of the world." A recent and well-documented report (Corcoran et al., 2010) shows that conditions are dire already in many areas, both in terms of water quality and quantity. Overall statistics are that almost 900 million people do not have access to safe water. Some 2.6 billion, roughly half the population of the developing world, do not have access to adequate sanitation. In spite of the general impression often given by the press, more people are currently dying from poor water quality than from war, terrorism, and other forms of violence (Corcoran et al., 2010). In terms of water quantity, one fifth of the world's population, or 1.2 billion people, live in areas of water scarcity, and this number is projected to reach 3 billion by 2025 as water stress and populations increase. As large as they are, these numbers may still underestimate the true extent of the problems in some parts of the world (e.g., Zawahri et al., 2011).

Some of the problems related to the availability of water resources in large enough quantities and of sufficient quality are long-standing. However, a number of severe problems have appeared only in the last ten years. Among them, one of the most significant is related to the exploitation of shale gases. Shale formations in various parts of the world (Fig. 1) have been known for a long time to contain significant amounts of natural gas, but in the past only shallow, fractured shale formations could be exploited economically. A technique known as "hydraulic fracturing" or "fracking", developed right after WWII, allowed natural gas from artificially-fractured, deeper shale formations to be recovered, yet the need to drill multiple vertical wells to large depths made the process too costly. In the early 2000s, major technological breakthroughs in terms of horizontal drilling (Fig. 2), combined with hydraulic fracturing, for the first time allowed access to large volumes of untapped shale gas resources, and led to a massive increase in exploration and drilling (Kargbo et al., 2010; Mooney, 2011).

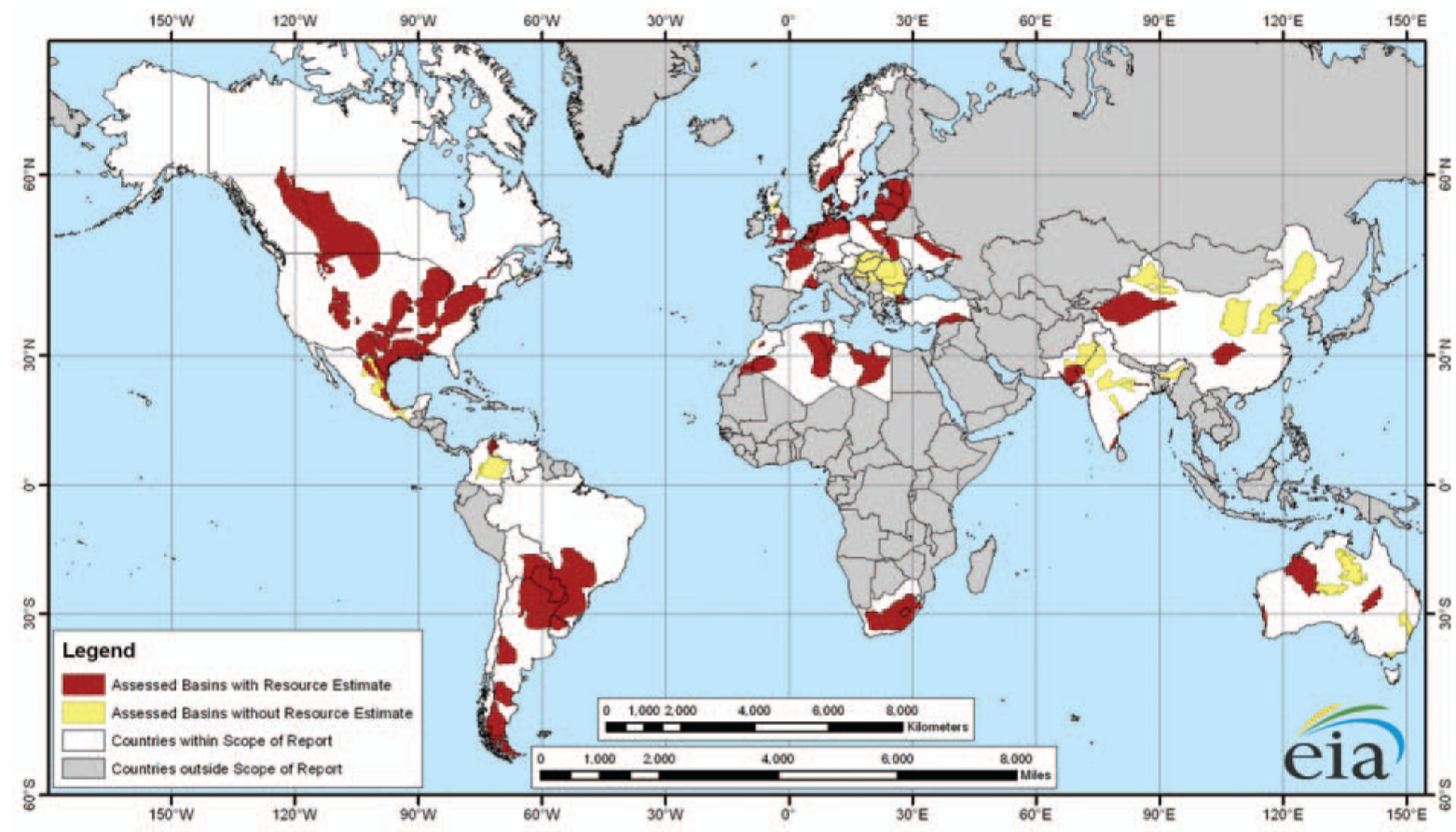

Fig. 1. Map of world shale gas resources assessed by the United States Energy Information Administration. (Adapted from EIA, 2011.) 


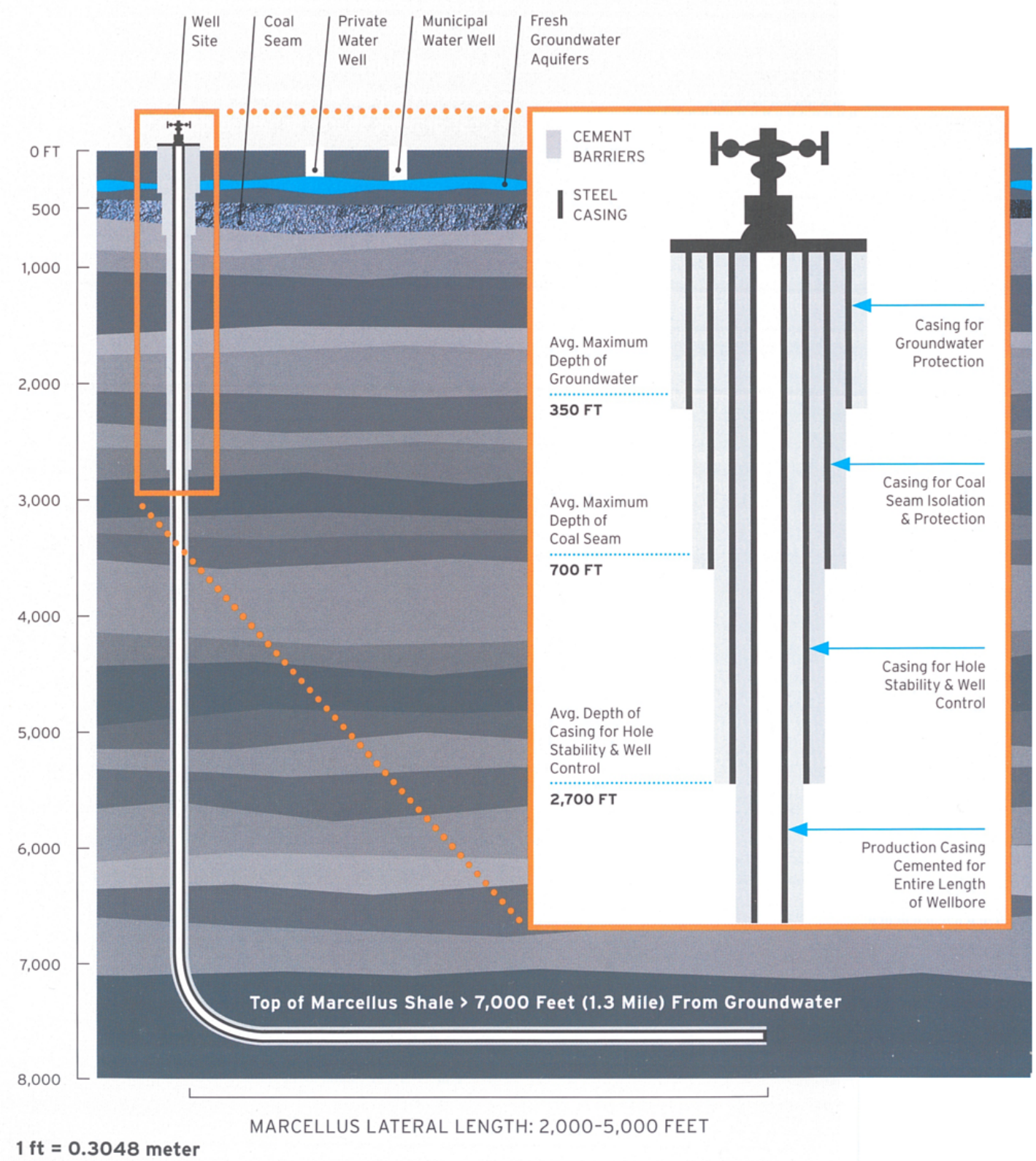

Fig. 2. Schematic of the process of hydraulic fracturing to exploit shale gas in the Marcellus shale in the Northeast of the US. (Adapted from Issue 5 of Chevron's magazine Next, September 2012.)

Ever since, public opinion has been extremely polarized on the topic, all over the world. Gas and oil companies, standing to derive trillions of dollars from exploitation of shale gas, have lobbied extensively to promote it, and are willing to invest heavily into new operations, as is demonstrated by last year's 4.5 billion dollars investments of French and Chinese gas companies into the development of US gas shales. Governments also stand to benefit from the operation, in the form of taxes or increased energetic self-reliance, as well as from the fact that natural gas may be used as a "bridge" until renewable, nonfossil energy sources become more economically appealing to policy-makers than they are for the time being. In the US, where real estate owners have full subsurface mineral rights, individuals in economically depressed areas tend to see in fracking an unexpected bonanza and have committed in droves to gas production under their land. On the other hand, environmentalists from different horizons have raised numerous questions about potentially severe environmental risks associated with drilling and fracking operations. The very high spatial density of wells needed to exploit shale gas, the large amounts of water needed to frack, the release in surface waters and waste water streams of hundreds of often extremely toxic (cancer-causing, endocrine-disrupting) chemicals used in fracking, the heavy truck traffic associated with the transport of these chemicals and of the gas, the risk of directly or indirectly contaminating shallow aquifers, and more recently, earthquake hazards, are among the many causes for alarm that environmentalists raise (Entrekin et al., 2011; Rozell and Reaven, 2012).

Some of these environmental concerns might be resolved if gas companies adopted a different technique to fracture shales, for example a technology that does not use water, but employs liquid $\mathrm{CO}_{2}$ or some other liquid instead (Rogala et al., 2013). However, unless someone invented an ingenious device that can be lowered into the shale itself and can collect and purify the natural gas in situ, all problems would not be resolved and worries would still persist. Indeed, many industry reports indicate that the portion of the gas wells near the soil surface, which passes through aquifers (Fig. 2), has issues of its own. 


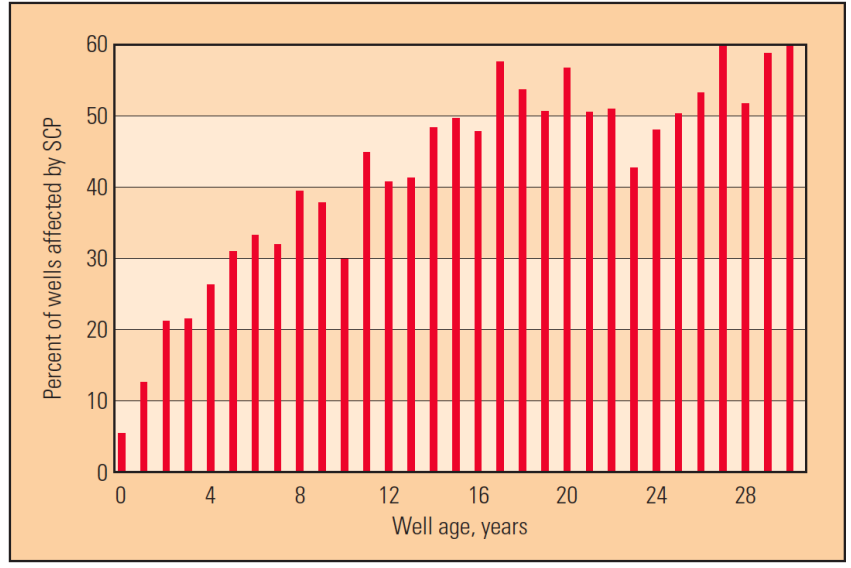

Fig. 3. Wells with sustained casing pressure (SCP) by age. Statistics are from the United States Mineral Management Service (MMS) show the percentage of wells with SCP for wells in the outer continental shelf area of the Gulf of Mexico, grouped by age of wells. (From Brufatto et al., 2003.)

After a well is drilled and before it starts producing, a number of concentric cement casings are poured in place around the well pipes. The integrity of these casings is crucial to the protection of groundwater resources. Unfortunately, the drilling industry, and in particular, its world leader, Schlumberger, acknowledge that well cementing is fraught with technical problems: "Despite recent advances in the cementing of oil and gas wells, many of today's wells are at risk." (Nelson et al., 2006). Brufatto et al. (2003) describe in detail some of the possible causes of uncontrolled gas migration in a traditional gas well, and conclude that "Since the earliest gas wells, uncontrolled migration of hydrocarbons to the surface has challenged the oil and gas industry. Gas migration, also called annular flow, can lead to sustained casing pressure (SCP), sometimes called sustained annular pressure (SAP). [...] Annular flow and SCP are significant problems affecting wells in many hydrocarbon-producing regions of the world." The statistics that Brufatto et al. (2003) present suggest that at the time of construction of the casings, about $5 \%$ of them fail, i.e., show signs of SCP. After a few years, this proportion increases rapidly, to reach close to $60 \%$ after 18 years (see Fig. 3). This means that in a region like the northeast US, where hundreds of thousands of drillings are planned, there could easily be five to ten thousand wells leaking natural gas and a cocktail of hundreds of toxic, sometimes radioactive, chemicals into neighboring aquifers, right when the exploitation of the shale gas starts. As many as a hundred thousand wells might be leaking a few years later, even if at that point the wells have been capped. As large as it is, this estimate may still be conservative; the water moving upward in wells in the case of shale gas production is likely to be acidic and laden with $\mathrm{H}_{2} \mathrm{~S}$ (because of the activity of sulfate reducers in the shale), which is expected to threaten the integrity of well cement casings even more than in regular gas or oil wells.

This very pessimistic outlook should encourage the community of hydrologists and water resources specialists to think about possible actions. One possibility is to educate policymaker about the uncharted risks involved in drilling through aquifers with a technology that is still untested, and does not appear currently to be sufficiently robust. Beyond that, it is clear that "baseline" data of surface water and, whenever feasible, groundwater quality are needed urgently in the parts of the world where shale gas exploitation is envisaged. In many cases, such baseline monitoring data do not exist at all. Surface water quality data could be obtained without significant financial support, for example in the context of practical exercises associated with hydrology or water resources courses taught in universities. Students could be trained to take samples and analyze them, in the process contributing to build a data library that could be used at a later date to detect and quantify the extent of water contamination, if and when it happens. The monitoring of groundwater quality is trickier, in that it requires significant funding, which at the moment is not available in many countries. Perhaps, on a case-by-case basis, we could piggy-back on unrelated research projects dealing with groundwater resources, and add to them a component of water quality monitoring that could provide needed baseline data in regions overlaying shale formations.

In the broader scheme of things, we should probably be concerned also about parts of the world where there are conflicting demands on water, whether it be within a given region our country, or among neighboring nations (Darnault, 2008). Indeed, there is something that makes water-related conflicts particularly tricky for human societies to resolve, and often leads them to escalate... Water is the only natural resource (besides air) without which humans absolutely cannot cope. A reasonably constituted person can easily operate for one or two weeks without eating anything, but cannot survive very long without drinking water. This requirement, at the individual level, puts a premium on access to sufficient water resources, of adequate quality. At the level of populations, especially when it is combined by the vital needs of agriculture and industry for water, the vital requirement to have access to water helps explain why governments are at times adopting drastic measures to guarantee access to water resources, sometimes in ways that puts them on collision courses with neighboring countries.

A vivid example in this respect is afforded by the Colorado river in North America, which is a sizeable river when it goes through the Grand Canyon, but is generally reduced to a mere trickling when it crosses the border into Mexico, in spite of protracted complaints by Mexicans that the US are unfairly appropriating all the water. Probably an even clearer example of how far some groups of individuals are willing to go to satisfy their water consumption needs is what has been unfolding in Palestine over the last 45 years. The geology of the region is such that several aquifer basins are located under the West Bank: the Western, Northeastern and Eastern basins, which collectively constitute the Mountain Aquifer (Fig. 4a). Other key sources of the water in the region are the Jordan River, and the Coastal aquifer. The geological formation in which the mountain aquifer is located has a pronounced slope toward the west (Fig. 4b), with the practical consequence that the best locations to drill in the upper part of the western aquifer, as well as in the lower part, are located immediately east of the 1949 Armistice Line, i.e., in what by law should be Palestinian land. Estimates of the abstracting costs per $\mathrm{Mm}^{3}$ of groundwater per year demonstrate clearly that a number of very economical drilling locations (in Tulkarem and Qalqilya) are in Palestine (Fig. 4c). Argually to prevent terrorist incursions in Israel, the Israeli government (against the opinion of a very vocal but minority segment of its population) has built an 8 metres-tall wall, known as the "Israeli West Bank Barrier" or in Europe as the "wall of shame", which separates the West Bank from Israel. In fact, the siting of this wall in many places makes little sense unless it is meant to deprive Palestinians from access precisely to the parts of the West Bank where abstracting groundwater from the Western Aquifer is most convenient and 

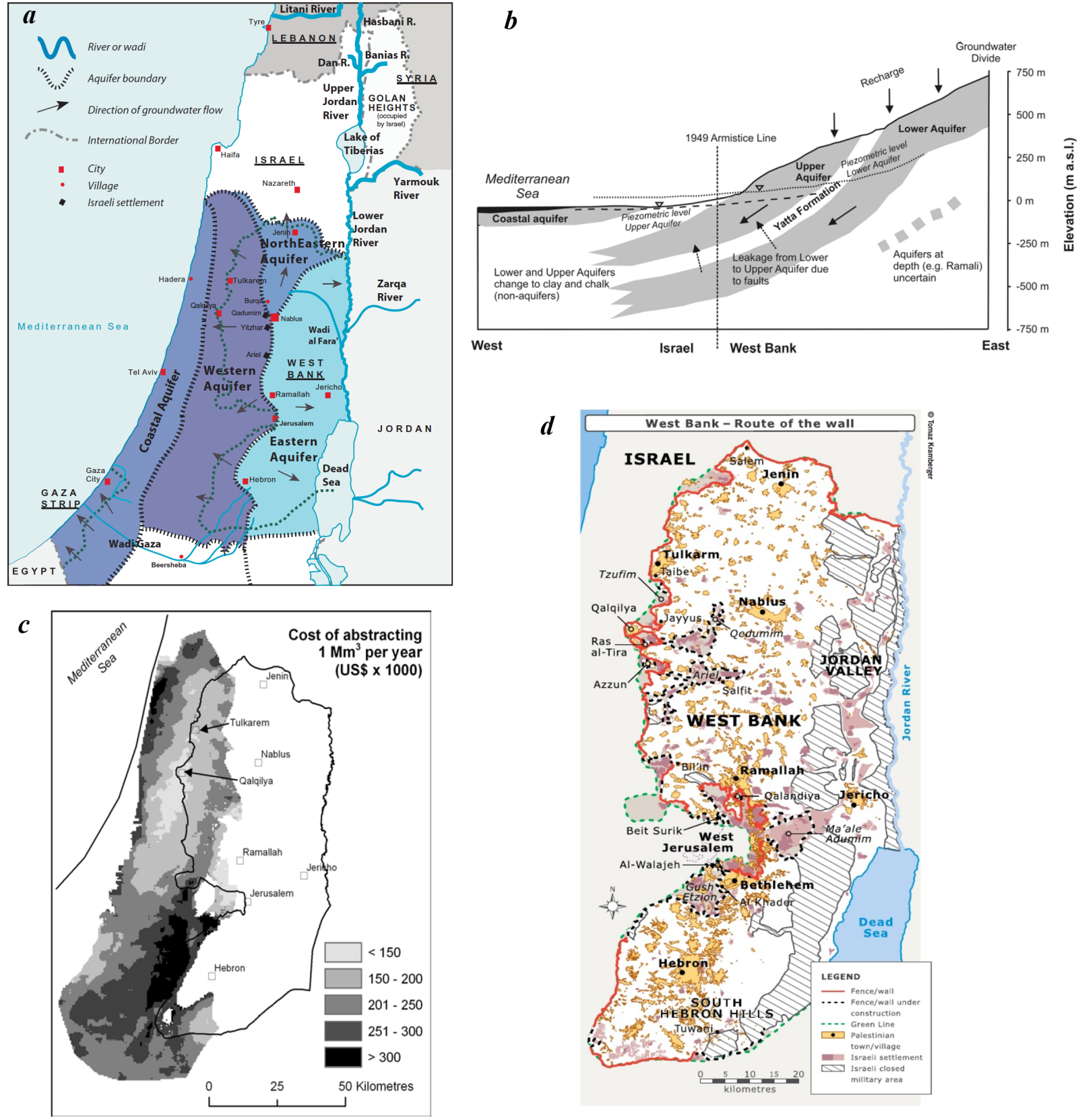

Fig. 4. a) Map showing the three mountain aquifer sub-basins and their average potential as defined in the interim agreement (adapted from Zeitoun et al., 2009). b) Schematic cross section of the Western Aquifer Basin from approximately Tel Aviv (west) to Ramallah (east). The coastal aquifer is also shown (adapted from McDonald et al., 2009). c) Groundwater development costs in the Lower Mountain Aquifer (adapted from McDonald et al., 2009). d) Map of Palestinian and Israeli settlements in the occupied West Bank, showing the location of the wall as of 2009 (reproduced from Amnesty International, 2009).

cheapest (Fig. 4d). In other locations, the construction of the wall itself has allowed the Israeli contractors to destroy Palestinian wells, or separate agricultural fields from the wells used traditionally to irrigate them.

The upshot of numerous decisions made by successive Israeli governments over the past decades is that most of the large water resources underneath the Westbank are not accessible to Palestinians. This situation has been condemned by numerous international organisations like the UN or Amnesty International (2009), foreign governmental institutions like the French parliament (Luca and Glavany, 2011), as well as numerous observers and researchers (e.g., Brooks and Lihton, 2011; Brooks and Trottier, 2010; Frederiksen, 2005; Hamdan et.al., 2011; MacDonald et al., 2009; Shomar, 2011; Tamimi, 2011;
Zawahri et al., 2011; Zeitoun et al., 2009), to no avail. At the moment (see Fig. 5), Israel takes $100 \%$ of the water from the Jordan River, $83 \%$ of the water from the Mountain aquifer, as well as $82 \%$ of the coastal aquifer, leaving for Gaza only very limited groundwater resources, of such poor quality that it causes significant health problems (Abbas et al., 2013). In many villages in the Best Bank as well as in Gaza, where water rationing is the rule, the amount of water available per capita per day is significantly below what the World Health Organization considers to be the minimum required to preserve satisfactory health. At the same time, Israeli settlers in the occupied territories enjoy unrestricted water supplies of over 300 liters per day per capita, well above WHO recommendations. 


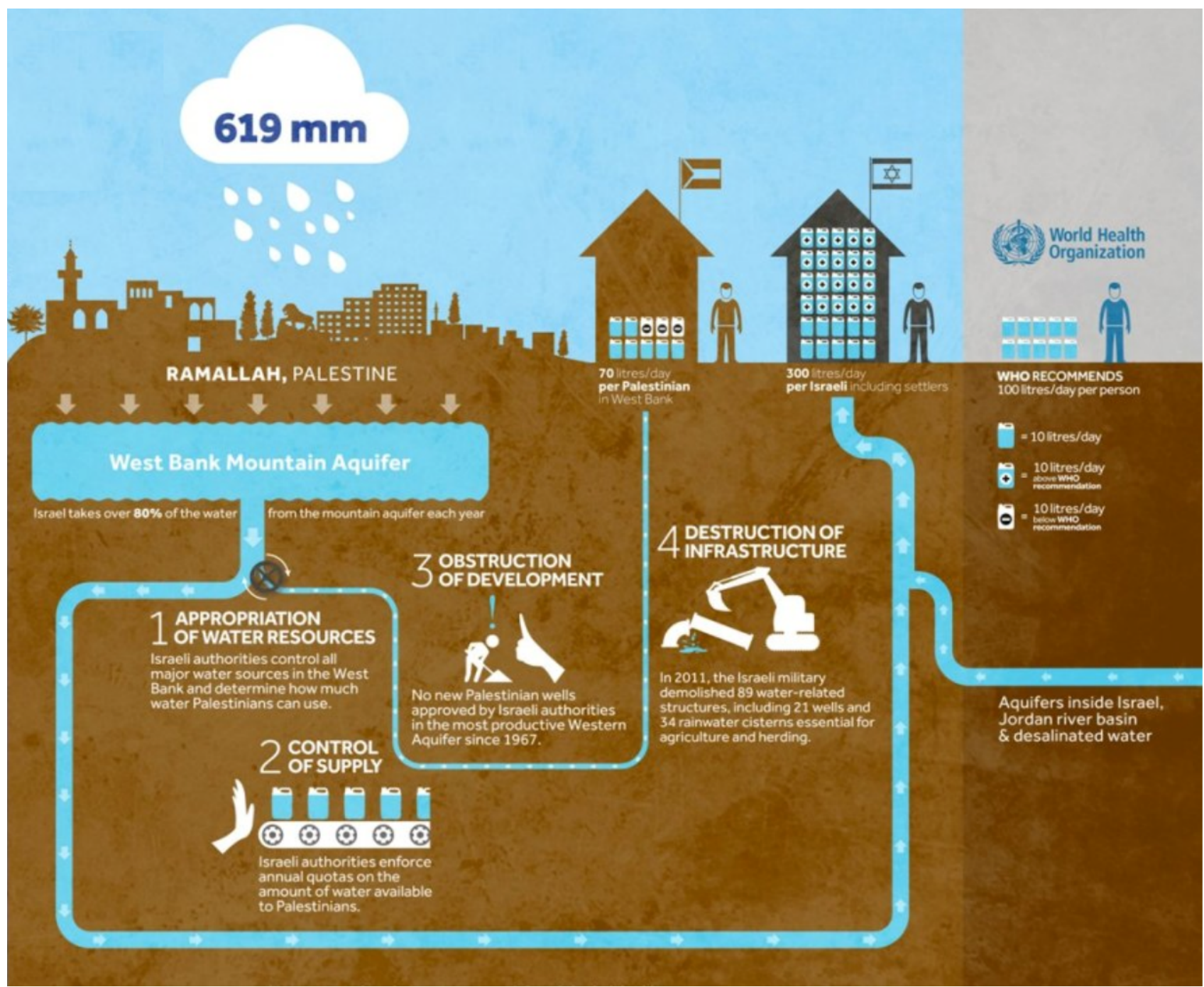

Fig. 5. Visual depiction of the appropriation of groundwater resources by the Israeli government (source: http://www.thirstingforjustice.org/wp-content/uploads/2013/ 03/WBL1.jpg; last accessed: April 30, 2013).

Certainly this situation in Palestine is extreme. Very few other governments would be willing, like the various right-wing governments of Israel over the past few decades, to ignore the opinion of most of the rest of the world, lose any moral credibility in the process, and engage in practices that are not only humanly reprehensible, but so clearly promote hatred and violence. Nevertheless, in other countries around the world, situations where surface- and groundwater resources need to be shared are extremely numerous and could turn out to be equally volatile if one is not careful. Hydrologists and water resources experts can help greatly diffuse some of the potentially explosive tensions that this sharing may generate. We can for example monitor carefully the use of the surface and groundwater resources, and make sure that it is within sustainable bounds. We can also monitor the quality of the water, and ensure that possible sources of pollution are avoided or at least minimized.

By demonstrating that in many cases, current uses of groundwater particularly are not sustainable (Anderson et al., 2012), hydrologists could also play a very significant role in leading a reflection on how we could do things differently, without consuming as much water as we do now. There are many possible routes to follow in this respect. One of them has to do with agriculture. For millenia, with very few exceptions, human societies have assumed that food needed to be produced on land. As rain becomes more erratic, at least in part of the world, and groundwater resources get overexploited, the time may have come to inquire whether, if one dares think "outside the box", a very different outlook is possible. From a resource allocation perspective, fully recognizing that water is as important, if not more important, to crop production than a soil material in which crops can propagate their roots, and that water will be scarce in many parts of the world in years to come, one would conclude that it would make sense to try to produce food where the water is. With the rare exception of countries like Brazil, that are blessed with abundant water supplies, in general the requirement to go where the water is would force us naturally to turn to the oceans, which cover 71 percent of the Earth's surface and contain 97 percent of the planet's water. Roughly two thirds of the world population already live in coastal areas around the world, so that deriving food and energy from the oceans would not pose insurmountable logistic problems. In addition, Japan has shown, for centuries, that it is possible to derive sizeable quantities of food from oceans. Different types of seaweed, sea vegetables, and countless fish products, often not consumed in other countries, find their way in the daily diet of the Japanese population. This example has been emulated by China in the last 25 years. Data compiled and reported by Liu and Diamond (2005) suggest that 
the production of aquacultured seafood has increased markedly since 1985. Some of the increase in production is associated with cultured freshwater operations, which most often use feed derived from land crops like soybeans and therefore do not change fundamentally the population's relationship with soils.

Nothing would prevent other countries, with less polluted coastal ecosystems, to jump on the bandwagon and to produce in the oceans, if not human food, at least animal feeds or sea crops that could be eventually converted into biofuels. If this trend toward a more widespread seafarming (Baveye et al., 2011; Radulovich, 2011) or mariculture materialized, soils would be less solicited for food production, and could be reforested to a far greater extent than at present, especially in erodable areas, or could be allowed more generally to be recolonized by their natural vegetation.

Hydrologists have important contributions to make in these different areas. The clock is ticking, inexorably. The water crisis that so many observers are forecasting is likely to be upon us before we know it. I hope that hydrologists and groundwater specialists will be ready to respond to the pressing demands society will make upon them in that context.

\section{REFERENCES}

Abbas, M., Barbieri, M., Battistel, M., Brattini, G., Garone, A., Parisse, B., 2013. Water quality in the Gaza Strip: the present scenario. Journal of Water Resource and Protection, 5, $54-63$.

Allison, L.E., 1947. Effect of microorganisms on permeability of soil under prolonged submergence. Soil Science, 63, 439-450 .

Amnesty International, 2009. Thirsting for justice: Palestinian access to water restricted. Amnesty International Secretariat, London, UK.

Anderson, R.G., Lo, M.-H., Famiglietti, J.S., 2012. Assessing surface water consumption using remotely-sensed groundwater, evapotranspiration, and precipitation. Geophysical Research Letters, 39, 16401, doi:10.1029/2012GL052400.

Baveye, P.C., 2010. Sticker shock and looming tsunami: The high cost of academic serials in perspective. Journal of Scholarly Publishing, 41, 191-215.

Baveye, P.C., 2011. Hydropedology, biohydrology, and the compartmentalization of hydrology into sub-disciplines: Necessary evolution or dispersal of efforts? Journal of Hydrology, 406, 137-140.

Baveye, P.C., 2012. Reflections while passing the baton: Hydrologists' input is direly needed in ongoing environmental and food-security debates. Journal of Hydrology, 438, 1-2.

Baveye, P.C., Laba, M., Otten, W., Bouckaert, L., Dello Sterpaio, P., Goswami, R.R., Grinev, D., Houston, A., Hu, Y., Liu, J., Mooney, S., Pajor, R., Sleutel, S., Tarquis, A., Wang, W., Wei, Q., Sezgin, M., 2010. Observer-dependent variability of the thresholding step in the quantitative analysis of soil images and X-ray microtomography data. Geoderma, 157, 51-63.

Baveye, P.C., Rangel, D., Jacobson, A.R., Laba, M., Darnault, C., Otten, W., Radulovich, R., Camargo, F.A.O., 2011. From dust bowl to dust bowl: Soils are still very much a frontier of science. Soil Science Society of America Journal, 75, 2037-2048 .

Brooks, D., Trottier, J., 2010. Confronting water in an IsraeliPalestinian peace agreement. Journal of Hydrology, 382, 103-114.

Brooks, D.B., Linton, J., 2011. Governance of transboundary aquifers: Balancing efficiency, equity and sustainability. In- ternational Journal of Water Resources Development, 27, 431-462.

Brufatto, C., Cochran, J., Conn, L., Power, D., Abd Alla ElZeghaty, S.Z., Fraboulet, B., Griffin, T., James, S., Munk, T., Justus, F., Levine, J.R., Montgomery, C., Murphy, D., Pfeiffer, J., Pornpoch, T., Rishmani, L., 2003. From mud to cement - Building gas wells. Oilfield Review, Autumn, 62-76 .

Budagovskyi, A.I., Novák, V., 2011a. Theory of evapotranspiration 1. Transpiration and its quantitative description. Journal of Hydrology and Hydromechanics, 59, 3-23.

Budagovskyi, A.I., Novák, V., 2011b. Theory of evapotranspiration 2. Soil and intercepted water evaporation. Journal of Hydrology and Hydromechanics, 59, 73-84.

Chen, X.-P., Cui, Z.-L., Vitousek, P.M., Cassman, K.G., Matson, P.A., Bai, J.-S., Meng, Q.-F., Hou, P., Yue, S.-C., Roemheld, V., Zhang, F.-S., 2011. Integrated soil-crop system management for food security. Proceedings of the National Academy of Sciences of the United States of America, 108, 6399-6404.

Corcoran, E., Nellemann C., Baker E., Bos R., Osborn D., Savelli H., (eds), 2010. 'Sick Water? The Central Role of Wastewater Management in Sustainable Development. A Rapid Response Assessment'. United Nations Environment Programme, UN-HABITAT, GRIDArendal. [accessible at: http://www.unep.org/pdf/SickWater_screen.pdf]

Darnault, C.J.G. (Ed.), 2008. Overexploitation and Contamination of Shared Groundwater Resources. Springer Science, Berlin, Germany.

Darnault, C.J.G., Garnier, P., Kim, Y.J., Oveson, K.L., Steenhuis, T.S., Parlange, J.Y., Jenkins, M., Ghiorse, W.C., Baveye, P., 2003. Preferential transport of Cryptosporidium parvum oocysts in variably saturated subsurface environments. Water Environment Research, 75, 113-120.

DeLeo, P.C., Baveye, P., 1997. Factors affecting protozoan predation of bacteria clogging laboratory aquifer microcosms. Geomicrobiology Journal, 14, 127-149.

Delozada, D.S., Vandevivere, P., Baveye, P., Zinder, S., 1994. Decrease of the hydraulic conductivity of sand columns by Methanosarcina barkeri. World Journal of Microbiology \& Biotechnology, 10, 325-333.

Doležal, F., Matula, S., Barradas, J.M.M., 2012. Improved horizontal installation of large soil moisture content sensors and interpretation of their readings in terms of preferential flow. Journal of Hydrology and Hydromechanics, 60, 333-338 .

Entrekin, S., Evans-White, M., Johnson, B., Hagenbuch, E., 2011. Rapid expansion of natural gas development poses a threat to surface waters. Frontiers in Ecology and the Environment, 9, 503-511.

Falconer, R.E., Houston, A.N., Otten, W., Baveye, P.C., 2012. Emergent behavior of soil fungal dynamics: Influence of soil architecture and water distribution. Soil Science, 177, 111-119 .

Fendeková, M., Fendek, M., 2012. Groundwater drought in the Nitra River basin - Identification and classification. Journal of Hydrology and Hydromechanics, 60, 185-193.

Foley, J.A., Ramankutty, N., Brauman, K.A., Cassidy, E.S., Gerber, J.S., Johnston, M., Mueller, N.D., O'Connell, C., Ray, D.K., West, P.C., Balzer, C., Bennett, E.M., Carpenter, S.R., Hill, J., Monfreda, C., Polasky, S., Rockstrom, J., Sheehan, J., Siebert, S., Tilman, D., Zaks, D.P.M., 2011. Solutions for a cultivated planet. Nature, 478, 337-342.

Frederiksen, H., 2005. Return Palestinian water rights if not land: A proposal. Middle East Policy, 12, 72-78. 
Gupta, R.P., Swartzendruber, D., 1962. Flow-associated reduction in the hydraulic conductivity of quartz sand. Soil Sci. Soc. Amer. Proc., 26, 6-10.

Hamdan, S.M., Nassar, A., Troeger, U., 2011. Impact on Gaza aquifer from recharge with partially treated wastewater. Journal of Water Reuse and Desalination, 1, 36-44.

Hanel, M., Vizina, A., Máca, P., Pavlásek, J., 2012. A multimodel assessment of climate change impact on hydrological regime in the Czech Republic. Journal of Hydrology and Hydromechanics, 60, 152-161.

Hanjra, M.A., Qureshi, M.E., 2010. Global water crisis and future food security in an era of climate change. Food Policy, 35, 365-377.

Houston, A.N., Otten, W., Baveye, P.C., Hapca, S.M., 2013. Thresholding of computed tomography images of heterogeneous porous media by adaptive-window indicator kriging. Computers and Geosciences, 54, 239-248.

Jacobson, A.R., Dousset, S., Guichard, N., Baveye, P., Andreux, F., 2005. Diuron mobility through vineyard soils contaminated with copper. Environmental Pollution, 138, 250-259 .

Jury, W.A., Vaux, H., 2005. The role of science in solving the world's emerging water problems. Proceedings of the National Academy of Sciences of the United States of America, $102,15715-15720$

Jury, W.A., Vaux, H.J., Jr., 2007. The emerging global water crisis: Managing scarcity and conflict between water users. Advances in Agronomy, 95, 1-76.

Kargbo, D.M., Wilhelm, R.G., Campbell, D.J., 2010. Natural gas plays in the Marcellus shale: Challenges and potential opportunities. Environmental Science and Technology, 44, 5679-5684.

Kovář, P., Vrana, I., Vaššová, D., 2012. Stakeholder group consensus based on multi-aspect hydrology decision making. Journal of Hydrology and Hydromechanics, 60, 252-264.

Laba, M., Downs, R., Smith, S., Welsh, S., Neider, C., White, S., Richmond, M., Philpot, W., Baveye, P., 2008. Mapping invasive wetland plants in the Hudson River National Estuarine Research Reserve using quickbird satellite imagery. Remote Sensing of Environment, 112, 286-300.

Lichner, L., Holko, L., Zhukova, N., Schacht, K., Rajkai, K., Fodor, N., Sándor, R., 2012. Plants and biological crust influence the hydrophysical parameters and water flow in an aeolian sandy soil. Journal of Hydrology and Hydromechanics, 60, 309-318.

Liu, J.G., Diamond, J., 2005. China's environment in a globalizing world. Nature, 435(7046), 1179-1186.

Luca, L., Glavany, J., 2011. La géopolitique de l'eau. Rapport d'information. Commission des Affaires Étrangères, Assemblée Nationale, République Française, Paris, France.

Machlica, A., Horvát, O., Horáček, S., Oosterwijk, J., Van Loon, A.F., Fendeková, M., Van Lanen, H.A.J., 2012. Influence of model structure on base flow estimation unsing BILAN, FRIER and HBV-LIGHT models. Journal of Hydrology and Hydromechanics, 60, 242-251.

MacDonald, A.M., O’Dochartaigh, B.É.Ó., Calow, R.C., Shalabi, Y., Selah, K., Merrett, S., 2009. Mapping groundwater development costs for the transboundary Western Aquifer Basin, Palestine/Israel. Hydrogeology Journal, 17, 1579-1587.
McDonald, R., 2011. The coming global urbanization: What it means for freshwater provision. Journal American Water Works Association, 103, 20-21.

Mooney, C., 2011. The truth about fracking. Scientific American, 305, 80-85.

Nelson, E.B., Guillot, D., 2006. Well cementing (second edition). Schlumberger Educational Services, Sugar Land, Texas.

Němečková, S., Slámová, R., Šípek, V., 2011. Climate change impact assessment on various components of the hydrological regime of the Male river basin. Journal of Hydrology and Hydromechanics, 59, 131-143.

Pavelková, H., Dohnal, M., Vogel, T., 2012. Hillslope runoff generation - Comparing different modeling approaches. Journal of Hydrology and Hydromechanics, 60, 73-86.

Qureshi, S., Richards, B.K., McBride, M.B., Baveye, P., Steenhuis, T.S., 2003. Temperature and microbial activity effects on trace element leaching from metalliferous peats. Journal of Environmental Quality, 32, 2067-2075.

Radulovich, R., 2011. Massive freshwater gains from producing food at sea. Water Policy, 13, 547-554.

Rogala, A., Krzysiek, J., Bernaciak, M., Hupka, J., 2013. Nonaqueous fracturing technologies for shale gas recovery. Physicochemical Problems of Mineral Processing, 49, 313-321 .

Rozell, D.J., Reaven, S.J., 2012. Water pollution risk associated with natural gas extraction from the Marcellus shale. Risk Analysis, 32, 1382-1393.

Schlueter, S., Weller, U., Vogel, H.-J., 2010. Segmentation of $\mathrm{X}$-ray microtomography images of soil using gradient masks. Computers \& Geosciences, 36, 1246-1251.

Schwartz, F.W., Ibaraki, M., 2011. Groundwater: A resource in decline. Elements, 7, 175-179.

Shomar, B., 2011. Water scenarios in the Gaza Strip, Palestine: Thirst, hunger and disease. International Journal of Environmental Studies, 68, 477-493.

Siegel, D., Baveye, P., 2010. Battling the paper glut. Science, 329, 1466-1466.

Slichter, C.S., 1905. Field measurements of the rate of movement of underground waters. United States Geological Survey Water Supply and Irrigation Paper.

Tamimi, A.A., 2011. Socioeconomic and environmental impacts of the Israeli Separation Wall. International Journal of Environmental Studies, 68, 557-564.

Thullner, M., Baveye, P., 2008. Computational pore network modeling of the influence of biofilm permeability on bioclogging in porous media. Biotechnology and Bioengineering, 99, 1337-1351.

Trimble, S.W., McKelvey, B., Grody, W.W., Gad-el-Hak, M., Siegel, D.I., Baveye, P.C., Bauerlein, M., 2010. Reward quality not quantity. Nature, 467, 789-789.

Vogel, H.J., Tolke, J., Schulz, V.P., Krafczyk, M., Roth, K., 2005. Comparison of a Lattice-Boltzmann model, a fullmorphology model, and a pore network model for determining capillary pressure-saturation relationships. Vadose Zone Journal, 4, 380-388.

Zawahri, N., Sowers, J., Weinthal, E., 2011. The Politics of assessment: Water and sanitation MDGs in the Middle East. Development and Change, 42, 1153-1177.

Zeitoun, M., Messerschmid, C., Attili, S., 2009. Asymmetric abstraction and allocation: The Israeli-Palestinian water pumping record. Ground Water, 47, 146-160. 